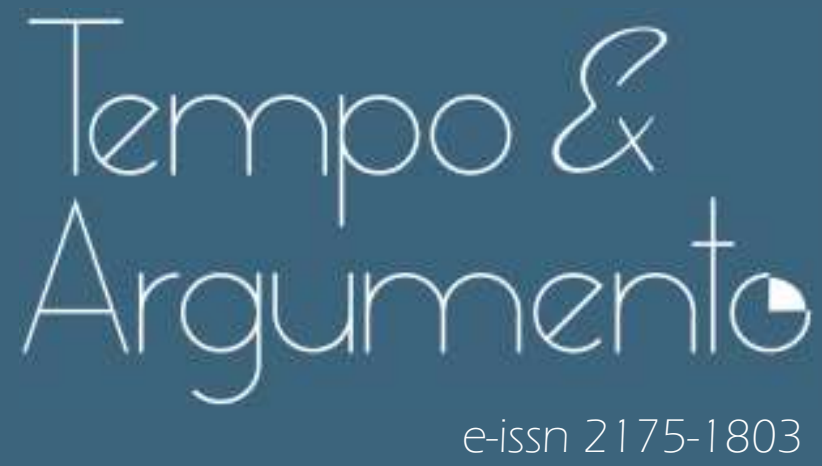

Reescrevendo a história. A contranarrativa sobre Moçambique contemporâneo a partir do Macuablogs (2004-2018)

- Luca Bussotti

Doutor em Sociologia do Desenvolvimento pela Universidade de Pisa (Itália). Professor Associado Visitante na Universidade Federal de Pernambuco (UFPE). Investigador no Centro de Estudos Internacionais do ISCTE-IUL (Lisboa). Recife, PE - BRASIL lattes.cnpq.br/8659437222936712 labronicus@gmail.com

(D) orcid.org/0000-0002-1720-3571

Para citar este artigo:

BUSSOTTI, Luca. Reescrevendo a história: a contranarrativa sobre Moçambique contemporâneo a partir do Macuablogs (2004-20 18). Tempo e Argumento, Florianópolis, v. 13, n. 34, e0104, set./dez. 2021.

do http://dx.doi.org/10.5965/2175180313342021e0104

Recebido: 04/05/2021 Aprovado: 08/09/2021 


\title{
Reescrevendo a história. A contranarrativa sobre Moçambique contemporâneo a partir do Macuablogs (2004-2018)
}

\begin{abstract}
Resumo
A narração histórica de Moçambique independente teve como suas fontes essenciais as testemunhas diretas dos que protagonizaram a luta de libertação e depois, exerceram papéis significativos no Estado independente, a partir de 1975. Foi esta narração que formou uma historiografia que se tornou oficial, sendo esta contestada por diversas orientações, desenvolvidas quer dentro, quer fora de Moçambique. A pesquisa aqui_apresentada tenciona proporcionar o ponto de vista de tais tendências presentes na plataforma online macuablogs, intitulado "Moçambique para todos" (https://macua.blogs.com/moambique para todos/) que expressa uma contranarrativa à história nacional, embasada numa visão política de crítica à Frelimo e seu governo. A pesquisa selecionou todos os artigos de natureza histórica publicados no site, analisando os assuntos principais, e complementando o trabalho com a entrevista ao fundador e gestor do blogue, o português Fernando Gil. O resultado foi de que as evidências encontradas abriram novos espaços para um debate público e largo sobre a história de Moçambique, com ênfase especial pela luta de libertação, oferecendo documentação interessante para o trabalho do próprio historiador profissional.
\end{abstract}

Palavras-chave: historiografia oficial; revisão historiográfica; luta de libertação moçambicana; violação dos direitos humanos.

\section{Re-writing history. The counternarrative on contemporary Mozambique based on Macuablogs (2004-2018)}

\begin{abstract}
The historical narrative of Mozambican as an independent State had, as its main sources, the direct witnesses who carried out the struggle for liberation and thus exerted important roles in the new independent State, starting from 1975. It was this narrative which formed a historiography which became official, contested by different orientations, developed as inside, as outside Mozambique. The research here presented aims at providing the point of view of one of these tendencies, that of the site online macuablogs, whose title is "Mozambique for all" (https://macua.blogs.com/moambique para todos/), which expresses a counternarration of a national history, embedded in a political vision contrary to Frelimo and its government. This attempt is made starting from a political position contrary to the current government led by Frelimo. This research selected all the historical articles published in the site, analyzing its main issues, complementing such work with an interview to the founder and manager of the blog, the Portuguese Fernando Gil. As a result, the evidences discovered opened a new room for a public and broad debate to rethink Mozambican history, providing an interesting documentation for the work of the professional historian.
\end{abstract}

Keywords: official historiography; historiographical review; mozambican struggle for liberation; human rights violation. 


\section{Introdução}

O "tempo do mundo" para o moçambicano moderno inicia em 1962, com a fundação da Frelimo' e o subsequente desencadear-se da luta de libertação nacional contra o colono português (PATRAQUIM, 1999). Tal tempo sempre foi considerado pela historiografia oficial como sendo linear e inquestionável, o que originou posicionamentos contrários a esta narração, a partir de pontos de vista diferentes do dos vencedores (RATTI, 2013).

A pesquisa aqui apresentada usa dois conceitos básicos: o de historiografia oficial e o de contranarrativa historiográfica. Em Moçambique a historiografia "oficial"_existe e foi plasmada pela narração da Frelimo, desde a altura da luta de independência. Já em 1971 o Departamento de Educação e Cultura da Frelimo publicou, no Porto, pelas Edições Afrontamento, uma primeira História de Moçambique, contraposta à narrativa colonial (BARBOSA RIBEIRO, 2015). Com a obtenção da independência, o Ministério da Educação e Cultura, criado em 1975, produziu (em 1977) o programa de história da 5 a à 9a classes, que se tornou a referência única para os jovens estudantes de Moçambique independente. Em 1978, o partido Frelimo publicou um manual também "oficial" de História da África. Como escreve Barbosa Ribeiro, "nos manuais escolares de História desse período (fim dos anos 70, anos 80 e 90), a História da FRELIMO e das lutas anticoloniais são o fio condutor dos conteúdos ali apresentados" (BARBOSA RIBEIRO, 2015, p. 21). Até hoje, no site do Governo moçambicano está patente essa leitura orgulhosamente ostentada. ${ }^{2}$

Se o objetivo da incipiente narrativa historiográfica oficial era de superar a visão colonialista do passado recente de Moçambique, contribuindo à emancipação de um povo ainda em formação, tal tentativa marginalizou aqueles elementos contrários aos princípios da nova nação, impondo um ponto de vista não passível de qualquer crítica.

\footnotetext{
* Nesse texto optou-se por manter a grafia da língua nativa

1 Frelimo é o acrónimo de Frente de Libertação de Moçambique, o movimento que, a partir de 1964 iniciou a luta de libertação contra o colono português e que sempre governou Moçambique, desde a sua independência em 1975 até hoje. Em 1977 a Frente se tornou partido político marxista-leninista, e hoje, depois da viragem de 1989, pertence à Internacional Socialista

2 Sobre isso, veja A luta pela Independência. In:

http://www.portaldogoverno.gov.mz/por/Mocambique/Historia-de-Mocambique/A-Luta-pelaIndependencia
} 
A contranarrativa que tentou opor-se à narração linear oficial nunca foi sistemática, aliás no período imediatamente posterior à independência propor perspectivas diferentes da narração historiográfica governamental era mesmo impossível. Com efeito, o conceito aqui usado de contranarrativa se refere a uma série de publicações e testemunhas diretas - que se manifestaram com a entrada de Moçambique no álveo das nações democráticas, a partir da década de 1990 - sobretudo da luta de libertação, que procuraram desmontar a narração oficial historiográfica da Frelimo, ostentando um posicionamento abertamente anti-governativo. Esta contranarrativa só se tornou possível no contexto da “Segunda República” iniciada formalmente em 1990 com a aprovação da primeira Constituição multipartidária. Entretanto, só a partir dos primeiros anos da década de 2000 é que emergiu uma contranarrativa consciente e sistemática, quando foi mais claro o tipo de governação pouco inclusiva que a Frelimo tinha estabelecido em Moçambique, apesar das aberturas formais da Constituição (CAHEN, 2011).

Os autores que compõem o mosaico complexo e heterogêneo desta contranarrativa são considerados como inimigos políticos por parte do PartidoEstado da Frelimo, não são geralmente historiadores profissionais (entre eles pode-se recordar Ncomo, Cabrita, Timóteo, Zeca Caliate), e abordam assuntos "tabus" do recente passado moçambicano, que o site macuablogs reproduz constantemente.

É interessante notar como a figura considerada como iniciadora desta corrente historiográfica, Bernabé Lucas Ncomo, autor do livro Uria Simango, um homem, uma causa, tem plena consciência do contexto em que a sua obra saiu. Numa entrevista feita ao jornal O Autarca, Ncomo esclarece que "o livro põe em causa a história oficial dum país", apesar de ser "um livro de rua, feito por um homem da rua”, destacando que foi um não académico a abanar o soporífero quadro historiográfico moçambicano (ACABOU-SE..., 2004). E um jovem intelectual, que irá se tornar Presidente do Conselho Municipal (Prefeito) de Quelimane, primeiro eleito nas fileiras do $\mathrm{MDM}^{3}$, depois da Renamo, Manuel de Araújo, considera o livro de Ncomo como a nova Bíblia da historiografia

MDM é o acrónimo de Movimento Democrático de Moçambique, o terceiro partido de Moçambique, fundado entre 2008 e 2009 por Daviz e Lutero Simango, filhos de Uria Simango, em rutura com a Renamo, de que faziam parte. 
moçambicana "alternativa" (ARAÚJO, 2004). No mesmo ano, Boaventura de Sousa Santos, numa entrevista reportada pelo blogue, expressa uma necessidade urgente: "Uma Comissão de Verdade e de Reconciliação Nacional em Moçambique", a fim de "questionar com alguma fundamentação, a história oficial da Frelimo e, portanto, a história contemporânea de Moçambique" (SANTOS, 2004).

O que estas vozes pretendem contestar é uma narrativa oficial que assenta numa visão linear da história recente do país. Esta inicia com o "mito fundador" da nação, correspondente à constituição da Frelimo, passa através do mito do "primeiro tiro" com que se inicia a luta armada contra o colono português, concluindo-se com a exaltação da obtenção da independência. A guerra civil que se combateu em Moçambique desde 1977 até 1992 é lida como um conflito originado por potências estrangeiras, cujo único objetivo era destruir o país. Em paralelo, uma galeria de heróis é proposta e imposta à opinião pública moçambicana: Eduardo Mondlane como o fundador da Frelimo e seu primeiro presidente, Samora Machel como o homem que trouxe a independência, mostrando uma postura ética irrepreensível, os antigos combatentes como pais nobres da pátria, Josina Machel como o símbolo da mulher moçambicana engajada e comprometida para com o destino da sua pátria.

A contranarrativa historiográfica propõe uma visão oposta, traçando cenários alternativos sobre as principais etapas da história do país: desde a revisão do "mito fundador" da Frelimo, em que Mondlane nem teria participado na reunião de constituição desta frente, até a própria luta de libertação, manchada por conflitos internos de cunho político e étnico, silenciados pela Frelimo, por terminar com a guerra contra a Renamo, considerada como conflito civil em prol da democracia, e não como simples obra de destruição do país por parte do potências reacionárias estrangeiras. Finalmente, Samora Machel, embora eticamente honesto, teria instaurado um estado de terror em Moçambique, eliminando brutalmente os dissidentes políticos nos ditos "campos de reeducação", particularmente na província do Niassa. Em paralelo, os heróis desta epopeia de resistência seriam, Uria Simango, antigo vice-presidente da primeira Frelimo de Mondlane, Joana Simeão, também morta nos campos de 
reeducação, que se contrapõe a Josina Machel como exemplo de mulher engajada, André Matsangaísse, fundador da Renamo e ultimamente Afonso Dhlakama, o líder histórico deste partido, falecido em 2018. Segundo esta leitura, os combatentes pela democracia deveriam ser equiparados aos combatentes pela liberdade, desenhando assim um panorama de eventos, projetos políticos e figuras de destaque completamente diferentes e até alternativos aos propostos pela historiografia oficial da Frelimo.

Tal contranarrativa não esgota os posicionamentos críticos em relação à historiografia oficial. Aliás, as leituras sobre o passado de Moçambique são inúmeras e diversificadas, confirmando a falta de sistematização da frente historiográfica que se opõe à historiografia oficial da Frelimo. De certa forma, o debate despoletado pelo macuablogs criou novo interesse mesmo na historigografia académica que não compactuava com a narração oficial da Frelimo, querendo ir além do discurso puramente governamental.

Por exemplo, Paula Meneses, moçambicana trabalhando na Universidade de Coimbra, evidenciou o elemento autoritário do Estado moçambicano, juntamente com as suas práticas de violência (MENESES, 2015; MENESES; SANTOS, 2009); Joseph Hanlon criticou em várias obras o modelo de desenvolvimento desigual adotado por Moçambique e sua elite (HANLON, 2010; HANLON; SMART, 2008); Newitt destacou na obra provavelmente mais completa da história de Moçambique desde a época pré-colonial, o fato de que "many Mozambican scholars have uncritically embraced the FRELIMO liberation script" 4 (ISAACMAN, 2019), com uma cómoda adesão às teses da historiografia oficial (NEWITT, 1995); Cahen estudou o papel da Renamo ${ }^{5}$ e da sua imagem, assim como a dificuldade de fazer de Moçambique um Estado-nação moderno, diante da complexidade cultural e linguística do país (CAHEN, 1992, 2002). E foi um brasileiro a estudar os casos de violação de direitos humanos nos campos de reeducação (THOMAZ, 2008). Historiadores moçambicanos tais como Cabaço, se

\footnotetext{
4 "Muitos estudiosos moçambicanos têm abraçado acriticamente o roteiro da liberação por parte da FRELIMO" (Tradução nossa).

${ }^{5}$ Renamo é o acrónimo de Resistência Nacional de Moçambique, uma formação político-militar que surgiu logo depois da independência moçambicana, desencadeou uma sangrenta guerra civil de 1977 até 1992 contra o Estado socialista, e representa hoje o maior partido de oposição do país.
} 
dedicaram à análise da identidade moçambicana no período colonial e durante a luta de libertação (CABAÇO, 2009). Um entre os poucos a levantar a questão da (re)escrita da história de Moçambique e da sua estreita relação com o poder oficial foi Borges Coelho, segundo o qual a Frelimo conseguiu transformar seu passado político em memória coletiva nacional (BORGES COELHO, 2019). Borges Coelho lança, portanto, um desafio epistemológico e historiográfico fundamental, convidando os historiadores moçambicanos a "entrar em competição" com o "Roteiro da Libertação" oficial e amplamente cristalizado.

Embora de forma simplificada, o quadro acima referido dá uma ideia da complexidade e pluralidade dos posicionamentos críticos que historiadores e outros cientistas sociais propuseram em relação ao passado recente de Moçambique. Entretanto, o que aqui se pretende destacar é que a importância da contranarrativa historiográfica que se aglutina em torno do site do macuablogs deve-se ao fato de este lançar aquele desafio epistemológico que Borges Coelho, Santos e em parte, Newitt, recomendam e que o blogue propõe desde a sua criação.

Foi esta a razão que fez com que se optasse por concentrar a análise da historiografia "alternativa" neste blogue (https://macua.blogs.com), criado em 2004 pelo português Fernando Gil. Como ele próprio explica (GIL, 2019), pelo fato de ter nascido e passado toda a primeira parte da sua vida em Nampula e arredores (terra da etnia Makhuwa), mais oito anos na tropa portuguesa em Cabo Delgado, lutando contra a Frelimo, sente-se Makhuwa, o que the empurrou para o desafio de desmascarar o poder, a corrupção e a violência do governo moçambicano.

O blogue - que desenvolve um sítio mais antigo, o Macua de Moçambique - foca a revisão historiográfica usando três fontes principais: artigos publicados em semanários independentes; comentários de livros da historiografia "alternativa"; testemunhas diretas sobretudo da luta de libertação que, em forma de cartas ou de intervenções, propõem as suas recordações e opiniões.

Com base em tais textos, se fez o levantamento completo das edições do macuablogs desde a sua fundação, em 2004, até 2018, para depois analisar os textos relacionados com alguns dos temas de maior impacto no debate público 
moçambicano. Para complementar o quadro foi feita uma entrevista com o próprio Fernando Gil, no sentido de esclarecimento de algumas dúvidas e inquietações provenientes da supramencionada análise.

\section{Breve enquadramento da historiografia africana contemporânea}

A historiografia oficial ou de Estado surgiu na Europa moderna. Entretanto, uma vez que o Estado-Nação se tornou a instituição política fundamental a nível internacional, a quase totalidade dos Estados independentes adotou - como seu marco identitário distintivo - uma narração feita por historiadores oficiais (PIIRIMÄE, 2017).

A base de tais narrativas assenta no "mito fundador" que geralmente diz respeito à epopeia da formação do Estado-Nação, passando por personagens lendários, grandes batalhas contra o inimigo invasor, finalmente vitórias memoráveis (HOBSBAWM, 1983).

O contexto africano não foge à regra. Aqui, o grande inimigo era representado pelos colonizadores europeus, a epopeia foi protagonizada pelos pais fundadores da pátria e do continente, e a vitória simbolizada pela independência nacional.

Em termos historiográficos, a viragem se deu com os oito volumes da História da África da UNESCO, iniciada em 1964 com a participação de historiadores tais como Ky-Zerbo, Anta Diop e muitos outros, visando escrever uma história do continente desprovida da típica visão eurocêntrica. Este grande empreendimento intelectual constituiu o primeiro ponto de referência para permitir que os estudiosos africanos se debruçassem finalmente de forma autónoma com o seu próprio passado.

Segundo Davidson, a nova historiografia africana surgiu em paralelo com o sucesso dos movimentos nacionais de libertação (DAVIDSON, 1959), em que povos e líderes locais assumiram um novo protagonismo, superando a ideia de que a história deste continente fosse "the history of Europeans in Africa" ${ }^{\text {(OGOT, }}$ 2011, p. 71, tradução nossa).

\footnotetext{
6 "A história dos Europeus em África."
} 
Os primeiros Estados independentes tiveram entre as suas tarefas principais, a releitura da história dos seus respetivos países, partindo de um ideal comum: o nacionalismo que resultou na independência. O cerne da nova história africana foi o colonialismo (DAVIDSON, 1971), aquele breve período que pareceu empurrar a historiografia africana para uma conceção historiográfica alternativa a ocidental e pós-colonial, mas que acabou reproduzindo quanto estava sendo feito na Europa e na América do Norte (DAVIDSON, 1971, p. 6). Mesmos mitos, mesma epopeia, mesma cristalização da narração histórica, que fez com que durante muito tempo se evitasse de falar dos problemas contemporâneos da África (AKE, 1996) ou, como defende outro historiador africano, sem investigar "why things went wrong"' (ELLIS, 2002, p. 7, tradução nossa).

A historiografia africana se deparou, numa primeira fase, com a edificação do Nation-Building; entretanto, a partir da crise financeira dos anos 1980-1990, que coincidiu com o fim da divisão em dois blocos do mundo e com o retorno de guerras étnicas e religiosas, a análise historiográfica local entrou em crise. Houve, por exemplo, uma queda significativa na produção histórica mesmo em revistas de renome, tais como o Journal of African History, / e em paralelo se multiplicaram os sites de Internet e blogues de matriz histórica, apresentando por vezes um material duvidoso, mas todavia útil para abrir o debate sobre as limitações da historiografia oficial (ELLIS, 2002). A ideia do glorioso nacionalismo africano também desmoronou dando espaço a críticas de tipo neoliberal, que por vezes voltaram a valorizar as experiências coloniais (FALOLA, 2003).

Assim, a grande dificuldade dos historiadores africanos se deparou com a necessidade de sair da cristalização historiográfica nacionalista e póscolonialista, sobretudo nos casos em que, como em Moçambique, nunca se verificou uma mudança na liderança política do país. O resultado foi, na maioria dos casos, a continuação de uma narrativa histórica de mera defesa dos ataques externos assim como das oposições internas com uma caraterística fundamental: "'nationalist historians' were themselves the creation of nationalist movements"8 (TOYIN, 2005, p. 504, tradução nossa).

\footnotetext{
7 "Porque as coisas correram mal."

8 Os "historiadores nacionalistas foram eles próprios o resultado dos movimentos nacionalistas."
} 
É neste quadro historiográfico dinâmico que o debate sobre o passado que está acontecendo até hoje em Moçambique deve ser colocado e interpretado.

\section{Um olhar histórico sobre Moçambique}

Moçambique alcançou a sua independência política a 25 de Junho de 1975, depois de um ano do "Governo de transição" liderado por Joaquim Alberto Chissano. Foi a partir da independência política que Moçambique edificou a sua epopeia histórica, formando uma historiografia oficial que se protelou mesmo com a abertura ao multipartidarismo (1990).

Uma boa parte da literatura especializada acreditou na narração que regimes como o moçambicano difundiram, segundo a qual "os partidos únicos africanos tinham como base de apoio a quase totalidade da população" (SOUSA JR., 2013, p. 21).

No caso moçambicano, a hegemonia da Frelimo, evidente na narração oficial, marginalizou o maior partido de oposição, a Renamo, subjugando e até eliminando as várias forças que se opunham ao projeto de independência a ser implementado (MENESES, 2015).

O novo Estado moçambicano, que em 1977 aderiu formalmente ao marxismo-leninismo, dotou-se de instrumentos sistemáticos para a escrita e a divulgação da história e a análise sociopolítica do presente, além dos manuais escolares. Os dois exemplos provavelmente mais notórios são: o Centro de Estudos Africanos (CEA), criado em 1976, associado à então única universidade do país, a Universidade Eduardo Mondlane, sediada em Maputo, e a revista Tempo, resgatando períodos e episódios do passado anticolonial (BESSA RIBEIRO, 2005; JUNQUEIRA BARRETO, 2011). A contestação de tal projeto político e de tal narrativa se manifestou mediante as armas. A Renamo protagonizou uma guerra civil iniciada imediatamente depois da independência, que dizimou cerca de 1 milhão de pessoas, destruindo uma boa parte das infraestruturas fundamentais do país (FUNADA CLASSEN, 2013; VINES, 2013). 
A própria guerra civil mereceu, de imediato, uma leitura clara e unilateral por parte da Frelimo: se tratava de "bandidos armados" que, aliados aos "reacionários" nacionais e internacionais estavam destruindo o país, minando as bases do novo Estado e do "Homem Novo" (MACAGNO, 2009). Esta imagem péssima permaneceu também entre os negociadores dos Acordos de Paz em Roma de 1992, protelando-se até aos anos seguintes e, em parte até hoje (BUSSOTTI, 2014).

A Frelimo procedeu em planos paralelos: por um lado, se reservou a exclusividade política de representação do povo moçambicano, como evidente sobretudo lendo a primeira Constituição de 1975 (em especial no art. 1 e 3); por outro, impôs o monopólio historiográfico nacional, transformando a primazia política em hegemonia cultural e em narrativa incontestável.

O fim da experiência socialista, oficialmente decretada em 1990, com a aprovação de uma nova Constituikção de inspiração liberal e o fim do monopartidarismo, determinou uma necessária viragem narrativa, que a Frelimo procurou gerir, não sem embaraços: o marxismo-leninismo foi rapidamente esquecido, graças também ao quadro internacional consequente à queda do Muro de Berlim, ficando desta experiência - inclusivamente em ambientes não exatamente próximos à Frelimo - o pendor ético da generosa tentativa de Samora Machel, passando por cima da componente política e ideológica (NGOENHA, 2010). Paralelamente, a narrativa oficial recuperou e enalteceu o mito fundador, cujo fulcro é constituído pela luta de libertação. O exemplo mais significativo é que o dia da independência, 25 de Junho, coincide com a fundação da Frelimo, configurando "uma relação umbilical" entre a epopeia libertadora e a constituição do Partido-Estado moçambicano (DINERMAN, 2007, p. 108).

A Frelimo nunca aceitou, nem depois da assinatura dos Acordos Gerais de Paz, a 4 de outubro de 1992, que o país repensasse e se refundasse segundo uma ideia de história nacional compartilhada, em que a Renamo (assim como qualquer outro sujeito) tivesse a mesma dignidade que o partido no poder. O dia 4 de Outubro foi declarado feriado nacional, mas sem que isso significasse um reinício da nação moçambicana. Em suma, o mito fundador da luta armada nos moldes contados pela Frelimo continuou e foi por isso que qualquer tentativa 
que a Renamo fez no sentido de mudar o novo hino de 2002 e a bandeira nacional naufragou sem apelo.

A historiografia oficial, além de estar patente nos manuais escolares, foi notabilizada - quanto ao período pré-colonial - por uma coletânea de volumes publicados por historiadores da Universidade Eduardo Mondlane que representa até hoje, uma referência incontornável para quem se queira aproximar ao passado deste país (CARVALHO, SERRA; MOREIRA, 1988; HEDGES et al., 1993; SERRA, 1983).

O conjunto das várias vozes que têm vindo expressar a necessidade de uma releitura profunda da história moçambicana encontra no macuablogs um ponto de convergência e de referência, que fez com que o presente estudo se concentrasse no material publicado por este blogue, e que é apresentado no ponto a seguir.

\section{O Macuablogs: um blogue político com interesses históricos}

No mundo lusófono e ainda mais em Moçambique, o macuablogs foi um precursor do uso das plataformas informáticas aplicado à leitura da história. Nos dias de hoje, os blogues disponibilizam fontes a que o trabalho histórico académico teria dificuldades em aceder. Se trata, portanto, de uma forma inovadora de reler o passado, inserida no debate público e político, de frequente em oposição aos regimes vigentes e à historiografia dos académicos, levada avante mediante critérios mais rigorosos (COLE, 2011).

A análise histórica feita através de blogues, portanto visa popularizar a história comum de um país e de um povo, superando as barreiras tradicionais e elitistas da historiografia profissional, que reflete largamente o ponto de vista do Estado ou dos académicos (HO, 2007). O blogue histórico permite aos não profissionais de expor suas ideias e experiências pessoais que se cruzam com a história pública, disponibilizando também novo material para os académicos.

O macuablogs não é um blogue de história; entretanto, o interesse para com a história acaba constituindo um elemento de relevo no contexto geral das suas publicações. Este blogue costuma contestar politicamente e eticamente o 
governo da Frelimo, como aparece em duas escritas destacadas e coloridas que afirmam: "O Partido Frelimo mata", e "O Partido Frelimo é ladrão". O interesse para com a história de Moçambique por parte do criador e gestor do blogue, Fernando Gil, prende-se com o fato de que diante de "tanta distorção" dos fatos não se pode ficar indiferentes (GIL, 2019).

O objetivo historiográfico do macuablogs é "mover as águas" de uma narrativa historiográfica ancorada a um processo de cristalização que parou à epopeia da luta de libertação, contada pelos próprios protagonistas e, portanto, largamente contestável por parte dos opositores políticos. A partir dessas bases, as intervenções no macuablogs são provocatórias e até bombásticas, com a finalidade de estimular um debate público em volta de assuntos históricos geralmente relegados a uma elite muito restrita.

Em termos metodológicos, o levantamento dos textos de matriz histórica publicados entre 2004 e 2018 resultou num total de 233 artigos, com uma tendência decrescente ao longo dos últimos anos. Ao mesmo tempo, existe um nível de concentração bastante elevado em 3 meses do ano, nomeadamente Junho, Setembro e Janeiro, que somam respetivamente 41, 28 e 25 ocorrências. A explicação tem a ver com as datas comemorativas de Moçambique, que tem a proclamação da sua independência em Junho (dia 25) e dois feriados em Setembro, dia 7 (Acordos de Lusaca com o governo português) e dia 25 (início da luta armada, mediante o primeiro tiro, supostamente disparado pelo General Chipande). O mês de Janeiro não tem acontecimentos marcantes na história de Moçambique, entretanto, sendo um mês com pouca atividade política devido à interrupção do início de ano, o blogue acaba dando maior espaço a reflexões e textos de cunho histórico. No geral, os últimos meses do ano são os mais pobres deste ponto de vista, inclusive Outubro, em que (dia 4) foi assinado o Acordo Geral de Paz em Roma em 1992 e em que ocorreu (n dia 19 o falecimento de Samora Machel.

O levantamento se baseou numa subdivisão temática, para melhor perceber quais assuntos foram os mais abordados, consoante a tabela 1: 
Tabela 1 - Divisão dos assuntos históricos por tema

\begin{tabular}{|l|c|}
\hline História de Moçambique & 59 \\
\hline História da Frelimo & 30 \\
\hline Direitos Humanos & 18 \\
\hline Primeiro Tiro & 10 \\
\hline Samora Machel & 14 \\
\hline Eduardo Mondlane & 06 \\
\hline Morte de Samora Machel & 23 \\
\hline Morte de Mondlane & 05 \\
\hline Morte de Magaia & 02 \\
\hline Uria Simango & 17 \\
\hline Graça Machel & 01 \\
\hline Matsangaísse & 03 \\
\hline Dhlakama & 01 \\
\hline Símbolos nacionais & 21 \\
\hline Descolonização & 10 \\
\hline Heróis da oposição & 13 \\
\hline Total & 233 \\
\hline
\end{tabular}

Fonte: elaboração do autor, 2020

Do levantamento quantitativo é possível tirar algumas primeiras ilações, a saber:

1. A categoria geral da "História de Moçambique" é a com mais ocorrências;

2. A segunda categoria mais abordada é a "História da Frelimo", concentrada no período da luta de libertação, o mais polémico para o macuablogs;

3. Os símbolos nacionais, juntamente com as datas celebrativas e especiais representam um assunto largamente abordado pelo blogue;

4. Particularmente cruas e desafiadoras são as matérias tratadas sob a rubrica dos "Direitos Humanos", relativas aos "campos de reeducação" (ou de “concentração", particularmente M’telela, na província do Niassa), com torturas e execuções sumárias; 
5. Entre os eventos pontuais, o que maior interesse despertou no blogue foi o "10 tiro". Se trata de um dos acontecimentos básicos do "mito fundador", amplamente contestado pela historiografia "alternativa";

6. Finalmente, existe uma atenção especial para personagens de relevo e, em alguns casos as causas e circunstâncias das suas mortes tais como, Eduardo Mondlane, Samora Machel, Filipe Samuel Magaia, do lado da Frelimo e outros como, Matsangaíssa, além de Uria Simango, do lado da Renamo ou da oposição no geral;

7. Um último aspeto vale a pena relembrado: entre os poucos blogguer que escrevem diretamente no Macuablogs pelo menos três deixaram marcas significativas: João Craveirinha, primo do maior poeta moçambicano, José Craveirinha, principalmente no primeiro período do blogue, com 13 artigos publicados, dos quais 10 entre 2004 e 2005. O jornalista Nhachote, com 9 artigos publicados, quase todos eles nos primeiros anos do blogue e tirados do semanário Canal de Moçambique; o comandante Zeca Caliate que, depois da publicação, em 2014, do seu Odisseia de um guerrilheiro, a partir de 2015 tem uma rubrica quase-fixa no blogue ( $A$ Voz da Verdade), com artigos extremamente contundentes contra a Frelimo e os seus chefes.

O ponto de vista do gestor do blogue é expresso mediante intervenções geralmente curtas, em jeito de comentário de artigos da historiografia oficial sendo que raras vezes, ele publica textos mais longos para manifestar o seu ponto de vista. Este estilo é assim motivado por Fernando Gil: "Tudo o que for extenso será menos lido. Prefiro colocar as minhas "farpas" sempre que oportuno e de mente aberta" (GIL, 2019).

\section{Uma outra história: a contranarrativa do Macuablogs}

Entre os muitos assuntos abordados pelo blogue e relacionados com a desconstrução da narrativa oficial será possível apresentar aqui apenas alguns dos principais, entre os quais: 
1. O mito "fundador", ou seja, a origem da Frelimo e a liderança de Mondlane;

2. A reabilitação de "reacionários" e sua transformação em "heróis da democracia";

3. A nova leitura sobre fatos fundamentais da luta de libertação, como o massacre de Mueda, o primeiro tiro, etc;

4. As mortes obscuras de personagens-chave da Frelimo tais como, Eduardo Mondlane, Samora Machel e Filipe Samuel Magaia;

5. As graves violações dos direitos humanos dos reeducados (presos) nos campos de M'Telela, Niassa.

1. O mito "fundador". As bases da história contemporânea de Moçambique (e da Frelimo) assentam numa narrativa que tem a ver, como explicado anteriormente, com a fundação do Partido-Estado. Entre os artigos publicados pelo macuablogs e que procuram desmentir uma tal versão é possível citar três, um da autoria de Luís Nhachote, publicado no Canal de Moçambique (NHACHOTE, 2006), o outro de Benedito Tomás Muianga, publicado no Savana (MUIANGA, 1995), cujo foco é o assassinato de Filipe Samuel Magaia, mas que aborda também a origem da Frelimo, e o último de Jaime Khamba, um dos fundadores da Frelimo que entrou em desavenças com este partido, e que publicou diretamente no blogue vários artigos de cunho muito polémico (KHAMBA, 2011). Em resposta, o macuablogs publica o posicionamento de Sérgio Vieira, que expressa a versão histórica oficial e “intocável” (VIEIRA, 2005).

Num tom de resgate de uma verdade que "dói, mas liberta”, Nhachote com base em documentos publicados no blogue - foca a sua atenção na fundação da Frelimo. Ele realça como o primeiro movimento nacionalista moçambicano, a UDENAMO ${ }^{9}$, terá sido fundado por Adelino Gwambe, ao passo que a fundação da Frelimo deu-se em Acra a 2 de Fevereiro de 1962, sem a presença de Eduardo Mondlane. Muianga corrobora uma tal tese, realçando que em Acra, os dois movimentos que se fundiram foram 
UDENAMO e MANU10 sendo que o terceiro, (a UNAMI), ${ }^{11}$ costuma ser associado por parte da historiografia oficial aos outros dois no momento de fundação da Frelimo, mas - segundo defende Muianga - ele foi criado depois da reunião de Acra, participando apenas da reunião de 25 de Junho de 1962 em Dar-es-Salaam, em que Mondlane foi eleito presidente. Finalmente, a intervenção de Khamba esclarece mais pormenores, inclusivamente respondendo às várias intervenções de Sérgio Vieira e ao silêncio de Marcelino dos Santos a propósito do assunto em questão. Khamba - segundo relata - esteve presente no encontro de Acra, na qualidade de representante da juventude, confirmando que os dois movimentos que se associaram para fundar a Frelimo foram a UDENAMO, com Gwambe, e o MANU, com Mmole. Também destaca que Marcelino dos Santos estava em Acra, integrado na delegação da UDENAMO, ao passo que os futuros "grandes" eram na altura completamente desconhecidos, inclusive Mondlane e o próprio Guebuza, que se juntou à FRELIMO em 1964. Em guisa de comentário, Fernando Gil afirma: "Assim sendo, não será a 25 de Junho de 1962 que a FRELIMO foi fundada! Quem diria!”.

Do outro lado, quem defende a versão historiográfica oficial é Sérgio Vieira que, numa sua intervenção no Boletim da FRELIMO sustenta que o grande arquiteto da operação de fusão dos três movimentos foi Eduardo Mondlane que considerava de tribalistas quer a UDENAMO, quer o MANU, concordando dar espaço à UNAMI, criada por Chissano e Mocumbi. Em Acra, segundo esta versão, terá havido um acordo prévio entre MANU e UDENAMO, de que Marcelino dos Santos informou Mondlane e os outros "grandes"; a UNAMI aderiu posteriormente.

Entretanto, além das testemunhas acima reportadas, o macuablogs publica os documentos originais assinados em Acra (na edição de 23/11/2011), enviados ao Fernando Gil por Khamba, que possuía uma cópia dos mesmos, e assim comenta: "Por favor moçambicanos, o dia 25 de

\footnotetext{
${ }^{10}$ Mozambique African National Union, um dos três movimentos que, em 1962, teriam confluído na Frelimo.

11 Acrónimo de União Nacional Africana de Moçambique Independente, fundada em 1961 por Baltazar Chagonga no Niassaland (atual Malawi), foi uma das três formações que, em 1962, deu origem à Frelimo.
} 
Junho não foi o dia em que a Frelimo foi fundada [...]. Há três pessoas presentemente em Moçambique que sabem o que aconteceu e onde isto aconteceu" (GIL, 2011), a saber: Marcelino dos Santos, Lopes Tembe Ndiramba e João Brito Munguambe. Este comentário e os documentos originais, escritos em língua inglesa e assinados por Mateus Mmole (MANU), Hlomulo Chitofo Gwambe (UDENAMO), com os dois secretários administrativos das duas formações, respetivamente Lourenço Milinga Milinga e Calvino Zeque Marayeye, representam evidências que contestam com bases sólidas a historiografia oficial. Este é o ponto de vista da contranarrativa historiográfica proposta através do macuablogs;

2. A reabilitação dos "reacionários". Na esteira do livro de Bernabé Lucas Ncomo, Uria Simango: Um Homem, Uma Causa, de que se referiu acima, a historiografia contrária à oficial inicia a delinear o seu panteão de figuras de referência. Uria Simango representa a contraparte de Mondlane. Simango, segundo esta leitura alternativa, foi quem tentou desviar o caminho da FRELIMO e do país do totalitarismo em que estava sendo mergulhado, assinalando esta perigosa tendência numa publicação de finais de 1969, Gloomy Situation in Frelimo, e pagando a sua derrota política com a vida sua e da sua esposa, Celina.

Além de Simango, outras figuras de "reacionários" encontraram a sua reabilitação no blogue de Fernando Gil. A mais destacada é Joana Simeão, o alter-ego da Josina Machel, professora de francês de origem Makhuwa, também regressada a Moçambique em 1974, em seguida às garantias dadas pelo general e na altura presidente da república portuguesa Spínola, de uma independência acompanhada por eleições livres e justas. O livro de Ncomo relata também o destino a que Joana Simeão teve de se submeter, resumido num artigo publicado no Canal de Moçambique por Luís Nhachote (NHACHOTE, 2009). Membro do Partido da Coligação Nacional, presidido por Uria Simango, foi presa na cidade da Beira a 26 de Outubro de 1974 por oficiais portugueses do MFA, que depois a entregaram às autoridades moçambicanas do governo de transição, apesar de uma petição no sentido contrário da interessada. Dai, Joana Simeão foi transferida para Tanzânia, em Nachingwea, submetida a novos 
interrogatórios e a seguir a julgamento popular, instruído por Sérgio Vieira. Condenada à pena de reeducação (uma pena que não existe em nenhum ordenamento), mudada para a base naval de Metangula e finalmente em M'telela, foi daqui transportada para parte incerta, juntamente com Uria Simango e Lázaro Kavandame, e - segundo novas fontes - queimada viva (provavelmente em 1977) - e não por fuzilamento, como narra a historiografia oficial, depois de regada com gasolina, e com a multidão que entoava cantos revolucionários, sob as ordens dos membros da FRELIMO. O quadro dos heróis da historiografia alternativa é completado por meio da figura de André Matsangaísse, "pai" da RENAMO. No caso dele, a tentativa de reabilitação por parte da RENAMO insere-se no seio da edificação de um novo mito fundador, contraposto ao da FRELIMO. Há três episódios importantes a se assinalar a respeito: o primeiro tem a ver com as celebrações em ocasião do 36ㅇaniversário da morte do Comandante Matsangaísse, ocorrida a 17 de Outubro de 1979, na Vila Paiva de Andrade (atual Vila da Gorongosa, Província de Sofala). Neste caso, a RENAMO, por intermédio do seu então Presidente, Dhlakama, encara a vida e as ações do "nosso saudoso Primeiro Comandante-em-Chefe" como um herói que lutou pela afirmação da democracia, mobilizando outros moçambicanos em prol de uma tal luta (MENSAGEM..., 2015). O segundo episódio diz respeito à intitulação de uma rotunda e à edificação de uma estátua na cidade da Beira, no bairro da Munhava, em homenagem a André Matsangaísse, em 2007. Estátua que foi amplamente contestada pela mesma RENAMO, alegando que ela não representaria o Matsangaísse e que foi erguida por pessoas (tais como o Daviz Simango) não pertencentes à RENAMO. Em 2009 a estátua foi abatida, devolvendo o nome originário à rotunda da Munhava (ALEGADA..., 2009). Finalmente, o último episódio cria um considerável embaraço nas fileiras da FRELIMO e, portanto, na historiografia oficial devido à sua carga simbólica. Matsangaísse seria o indivíduo que, a 25 de Junho de 1975, içou a bandeira moçambicana depois de a portuguesa ter sido amainada. "Um amigo" do Fernando Gil assim escreve no blogue: "É!!! Esse mesmo, que a nossa história só nos ensinou a chamá-lo de "Bando Armado" (SABEM..., 2007). 
3. Entre a revisão de episódios marcantes da história moçambicana que o macuablogs propõe, Fernando Gil julga que as três principais "mentiras" segundo o termo que ele costuma utilizar - da versão oficial sejam o massacre de Mueda, a ausência de Mondlane na fundação da FRELIMO e o "primeiro tiro" (GIL, 2019). É justamente disso que este ponto vai tratar. O primeiro tiro contra as tropas coloniais portuguesas pode ser inserido no seio do mito fundador de que se referiu no ponto 1, assumindo, porém, uma configuração própria. Com efeito, o dia do primeiro tiro, 25 de Setembro, representa uma das datas mais importantes para celebrar a moçambicanidade, sendo o dia das Forças Armadas. Quem mais insiste na versão oficial é o General Chipande, ou seja, o próprio jovem que na altura terá disparado o primeiro tiro. Os problemas que a sua versão apresenta do ponto de vista historiográfico são dois: acima de tudo, a ideia de que o ataque em Chai seja efetivamente o primeiro de toda a luta de libertação; o segundo diz respeito ao número de vítimas, que oscila entre duas, seis ou zero. A seguir serão apresentadas as diferentes versões ilustradas em vários artigos no macuablogs, destacando o posicionamento do blogue e do Fernando Gil na primeira pessoa - e tirando algumas conclusões quanto à fraca credibilidade da narração oficial do evento que precisaria de um trabalho de rigoroso apuramento dos fatos mediante o cruzamento das fontes.

Num artigo que o macuablogs reporta, Chipande - antigo Ministro da Defesa - defende que quem propõe uma versão contrária a oficial pretende "deturpar a história nacional", desafiando os críticos para apresentar provas concretas que desmintam uma tal narração. No relatório que escreveu sobre o assunto, chipande defende que "no primeiro ataque foi morto o chefe do posto, juntamente com seis outros portugueses" (CHIPANDE..., 2008). No dia seguinte, o Comité Central da FRELIMO, na altura em Dar-es-Salaam, certificou a versão de Chipande, propondo uma narração entre histórica e hagiográfica, assim declarando oficialmente: “Em vosso nome a FRELIMO proclama hoje, solenemente, a insurreição geral armada do povo moçambicano contra o colonialismo português" (ARAÚJO, 2018). Esta versão foi definitivamente assumida como 
a oficial através da revista de propaganda da FRELIMO Mozambique Revolution, n. 30 de 1967 (O MAPA..., 2019).

No macuablogs, Fernando Gil dá a conhecer leituras - inclusivamente semioficiais_- que desmentem o ponto de vista de Chipande e da FRELIMO. Por exemplo, uma investigação feita pelo ARPAC (Arquivo do Património Cultural), uma instituição subordinada ao Ministério da Cultura e, portanto, governamental, baseada em entrevistas junto a 35 pessoas nativas de Chai e na altura presentes naquela vila, concluiu que no ataque de 25 de setembro não houve mortos, mas que o primeiro morto português foi registado só uma semana depois, sendo este que era o cunhado do chefe do posto, que caiu numa emboscada, ao regressar do rio Messalo, onde tinha ido buscar água (CHIPANDE..., 2008). Neste caso, a fonte semioficial não retira a importância nem a veracidade do primeiro tiro e da sua paternidade a Chipande, mas sim questiona sobre o número das vítimas. Outras fontes desmentem de forma ainda mais radical a versão de Chipande. No mesmo artigo, Fernando Gil reporta uma testemunha ocular, do lado português, constituída por Manuel A.T. Alves, que na altura tinha 8 anos, e que defende que "ninguém morreu de ambos os lados, e lembrome quase tudo. Tudo se resumiu a 2 rajadas de metralhadora (uma de cada lado)" (CHIPANDE..., 2008). Outras testemunhas e autores confirmam que no ataque ocorrido em Chai ninguém perdeu a vida: é assim que defende João Craveirinha, com base no livro do ex-militar americano Major Lance S. Young (YOUNG, 1991), num artigo publicado no blogue (CRAVEIRINHA, 2004). Quanto ao fato de o ataque em Chai ter sido o primeiro da luta de libertação, o macuablogs levanta novas versões, que é possível aqui classificar segundo duas tendências: uma interna à FRELIMO que defende a teoria da impossibilidade em estabelecer quando e quem deu o primeiro tiro; a outra, mais radical, externa à FRELIMO que reverte por completo o cenário sobre o episódio em questão, abrindo perspetivas historiográficas que vão muito além dele.

No primeiro caso, o General Eduardo Nihia, conhecido como M’toto (“O pequeno", em Swahili e Emakhuwa), "o único Mmakhuwa da FRELIMO" naquela época, em entrevista ao jornal O País frisa que o primeiro tiro pode 
ter sido dado em qualquer das localidades das províncias da Zambézia, Cabo Delgado ou Niassa, mas que a primeira comunicação foi dada pelos camaradas que estavam em Cabo Delgado, Liderados por Chipande, devido à vizinhança com a sede central do movimento, em Dar-es-Salaam (RELATO..., 2010).

A outra versão, externa à Frelimo, apresenta uma leitura muito mais radical. Segundo testemunhas ouvidas pelo jornal Imparcial,12 o primeiro ataque terá ocorrido em Nangololo (Cabo Delgado), junto à missão católica daquela localidade, por parte alheia a FRELIMO, mas do grupo Makonde do MANU, em Agosto de 1964, matando um padre holandês (MANU disparou, 2005). Uma tal dinâmica enfatiza o papel de abre-pista por parte do MANU na luta anticolonial, em detrimento da FRELIMO de Mondlane.

4. A morte de figuras-chave do nacionalismo moçambicano, acima de tudo os primeiros dois presidentes da FRELIMO, Mondlane e Machel (este último também primeiro Presidente da República). A morte de Samora Machel ganha espaço no blogue a partir do livro escrito por João Cabrita (CABRITA, 2005a). As teses que o blogue apresenta são duas: a primeira é a oficial que sempre defendeu a existência de um atentado organizado pela África do Sul contra o avião presidencial, um Tupolev Tu-134, mediante o uso de um falso VOR (Very High Frequency Omnidirectional Range, um instrumento eletrónico normalmente utilizado na aviação civil). O VOR conseguiu enganar a tripulação soviética, induzindo-a a uma aterragem em terreno acidentado, fora do aeroporto de Maputo, onde o avião se terá despedaçado. Esta tese não fora acolhida pela Comissão de inquérito tripartida África do Sul-Moçambique-União Soviética (na época), razão pela qual Moçambique resolveu sair da mesma, a qual atribuiu a responsabilidade a uma falha técnica da tripulação soviética (conclusão corroborada pelas gravações da caixa negra). A segunda interpretação, em boa parte baseada nas conclusões da Comissão de inquérito, mas suportada por documentos novos é defendida pelo autor do livro, João Cabrita. O mesmo, numa entrevista, revela que o livro "é mais uma

12 Jornal privado criado em 1994 como jornal via fax, com ligações bastante evidentes ao partido Renamo. 
tentativa que fizera para apresentar uma versão diferente dos acontecimentos daquela que é hoje tida como a única" (LAS, 2005). Acima de tudo, Cabrita levanta uma crítica ao SNASP (antiga intelligence moçambicana, sob tutela do Ministério da Segurança, presidido por Sérgio Vieira), no sentido de que o avião presidencial devia evitar voar no espaço aéreo sul-africano, na altura inimigo de Moçambique (LAS, 2005). Em segundo lugar, Cabrita aponta pela “distração” da tripulação soviética com questões estranhas ao voo, tais como o uso de bebidas alcoólicas e conversas descontraídas. Finalmente, não haveria nenhuma prova do uso do falso VOR, pondo sérias dúvidas sobre a teoria oficial. Com base nas novas hipóteses de Cabrita, o debate a volta da morte de Samora Machel retoma folego. Por exemplo, o Mediafax, o primeiro jornal privado de Moçambique, distribuído na época (1992) via fax, publica um texto que procura desmentir outra componente da versão oficial, segundo a qual Samora Machel foi a Lusaka (Zâmbia), numa reunião internacional em missão de paz. Documentos que Cabrita apresenta no seu livro indicam que a missão em Lusaka fora de guerra, pois o objetivo era desestabilizar - com a ajuda do Zimbabwé - o regime de Banda no Malawi, que supostamente estava apoiando a RENAMO (CABRITA, 2005b). Na mesma senda, um dos maiores jornalistas moçambicanos, Salomão Moyana fala de "vaga acusação" de Moçambique ao governo sul-africano por ter organizado o atentado contra o avião de Samora Machel, sem, porém, nunca ter pedido um processo internacional contra as autoridades de Pretória na altura do apartheid (MOYANA, 2005). Com base em tais diferentes leituras, boa parte da "velha FRELIMO" não hesita a reagir. Paul Fauvet por exemplo, da Agência de Informação de Moçambique, acusa Cabrita (e Nhachote) de se ter inspirado aos "restos do apartheid", reeditando antigas alegações (FAUVET, 2005). Finalmente, Sérgio Vieira realça como o livro de Cabrita tem a sua base na PIDE (antiga polícia política portuguesa), sem entrar muito nos pormenores das argumentações (VIEIRA, 2005). Cabrita responde falando de "alegações francamente difamatórias, lesivas da minha dignidade" (CABRITA, 2005c), num debate mais virado para credibilidade das fontes do que para as 
questões de conteúdo. Finalmente, há quem chega a formular a hipótese de um envolvimento, além de figuras soltas do regime do apartheid, de descontentes da FRELIMO em relação ao regime de Samora (SIMBINE, 2006).

O debate sobre a morte de Eduardo Mondlane tem uma atenção menor por parte do blogue, em comparação com a morte de Machel, mas o teor é muito parecido. Neste caso, uma versão oficial (ou pelo menos que tal se pretende por parte do autor) existe, e é defendida por Sérgio Vieira. A ela se contrapõem outras de vária ordem por parte de figuras diversificadas, algumas das quais da primeira FRELIMO, outras de origem americana e sobretudo portuguesa, do lado da PIDE, até culminar com contribuições bibliográficas, tais como o livro Eduardo Mondlane: um homem a abater, de José Manuel Duarte de Jesus (JESUS, 2010), a que o blogue dá um bom espaço.

O macuablogs desenvolve, dentro do quadro acima ilustrado, o seu papel de apoio à pesquisa historiográfica alternativa, traçando de Mondlane um quadro de uma figura nem tão linear, como a historiografia oficial sempre quis deixar entender até fazer do dia da morte dele (3 de Fevereiro) o Dia dos Heróis Moçambicanos. Pelo contrário, nos artigos que o Macuablogs publica, Mondlane é de frequente encostado aos Estados Unidos e até a CIA, promotor de uma opção "moderada" em relação ao tipo de luta anticolonial a ser desencadeada nos anos Sessenta. A morte do primeiro presidente da FRELIMO - segundo as várias leituras da historiografia alternativa - foi em larga medida determinada pelo isolamento em que este acabou caindo, dentro e fora do movimento que liderava pelo que, as vicissitudes políticas estariam diretamente ligadas ao seu assassinato em Dar-es-Salaam. Em relação ao episódio em si, as questões abertas são três: quem preparou o livro-bomba que matou Mondlane; como é que ele chegou nas mãos de Mondlane, considerando todo o aparato de segurança a volta dele e onde é que Mondlane abriu o livro.

Quem elabora a teoria da exclusiva responsabilidade da PIDE é Sérgio Vieira. Segundo ele, do ponto de vista logístico, Mondlane teria recebido o livro-bomba - uma tradução francesa da obra de Plekhanov - ao sair do 
escritório, entrando para o carro dirigido por Silvério Nungo. A bomba terá sido preparada na Beira, entregue no Malawi a Jorge Jardim (o homem de confiança de Salazar em Moçambique) e Orlando Cristina (supostamente agente da PIDE), para dai chegar até Dar-es-Salaam. Vieira defende que esta não é uma versão, mas "a versão", oficial e incontestável (BARROSO, 2014).

Entretanto, várias lacunas são identificadas por parte da contranarrativa historiográfica. Sobre a logística, Vieira não teria a mínima prova sobre o papel de Jardim (que desmentiu qualquer envolvimento - ver o artigo Sérgio Vieira, 2009) e de Cristina (que parece não ser agente da PIDE, tendo iniciado a colaborar com Jardim depois de 1969). Da bomba armadilhada na Beira também não existe nenhuma prova (SÉRGIO..., 2009). Pelo contrário, fontes alternativas publicadas no Macuablogs (ASSASSíNIO..., 2004) apontam para um cenário completamente diferente. Acima de tudo, a PIDE tinha um grupo de informadores dentro da FRELIMO, como confirma António Vaz, responsável da PIDE-DGS em Moçambique, trazendo provas a este propósito. A bomba que matou Mondlane foi provavelmente preparada por Casimiro Monteiro, segundo duas testemunhas diretas do fato (entre as quais Oscar Cardoso, inspetorajunto da PIDE-DGS); entretanto ainda não se sabe quem tivera conhecimento da encomenda para Mondlane. Cardoso chega até a lançar uma provocação, afirmando que teve a colaboração do chefe da segurança de Mondlane, Joaquim Chissano, futuro presidente de Moçambique. Fora de uma tal provocação, a PIDE tem a certeza de que houve uma colaboração interna à FRELIMO, e o maior indiciado para tal cumplicidade seria Silvério Nungu, morto poucos meses depois (ASSASSíNIO..., 2004), pelas mãos da FRELIMO (CRAVEIRINHA, 2003b). Declarações quer de Silva Cunha, membro do governo, quer de Salazar, quer de Caetano, assim como do António Vaz reforçam que Mondlane "era o mal menor", certamente preferivel a Samora Machel, de tendências mais radicais. A versão tanzaniana aponta também por cumplicidades dentro da FRELIMO, mas nesse caso em colaboração com a PIDE; os dois indiciados seriam Lázaro Kavandame e Silvério Nungu. Várias outras fontes, quase todas elas dos 
serviços europeus de intelligence, indicam o envolvimento de Casimiro Monteiro como o autor material do assassinato (ASSASSÍNIO..., 2004). Mesmo a nível da logística e da segurança, a versão oficial de Sérgio Vieira encontra reparos a partir da própria FRELIMO. Joaquim Chissano fornece esclarecimento sobre as duas questões. Em declarações junto ao Canal de Moçambique (NHACHOTE, 2006), Chissano recorda que Mondlane foi morto em casa da americana Betty King, secretária da sua esposa Janet, onde costumava passar seus momentos de lazer (segundo confirma a própria Janet Mondlane) e não no seu escritório. Nhachote conclui com as seguintes palavras: "A versão 'oficial' [...] cai por terra, e encontra aconchego no pantanoso charco da história recente do país" (NHACHOTE, 2006). Acerca da segurança, Chissano revela que a FRELIMO estava ciente do risco que Mondlane corria, mas não admite nenhum deslize, uma vez que o inimigo - segundo conta - agiu de "forma diferente" do habitual, não usando emboscadas ou um atentado. Alias, Chissano realça que" a morte dele foi um deslize, digamos, do próprio Presidente Mondlane, que gostava de andar sozinho, como ele gostava de conduzir" (FRELIMO..., 2012).

5. O assunto relativo às violações dos direitos humanos por parte da FRELIMO é um dos mais polémicos do blogue e revelador de uma historiografia completamente adversa à oficial. O blogue tenciona mostrar como as atrocidades perpetradas pela FRELIMO foram não só gravíssimas, mas em muitos casos desnecessárias, humilhantes e gratuitamente cruéis. Assim, artigos de jornais privados e de bloggers que escrevem diretamente para o Fernando Gil, tais como João Craveirinha, Mussandipata, Zeca Caliate e outros, procuram desmentir a narração oficial da eliminação física dos "reacionários" como necessária naquela altura histórica.

A maior atenção do blogue está concentrada na experiência dos "campos de reeducação", interpretados aqui como "campos de concentração". Tais campos, designados de "laboratórios de criação do homem novo" por Samora Machel, funcionavam autonomamente dos órgãos de justiça, estando á merce do Departamento de Segurança da Frelimo e do Ministério da Segurança/SNASP, consoante o Decreto 21/75 (NÃO..., 2010). Fernando Gil sublinha que, no seu art. 5, o Decreto deixava ao SNASP a 
liberdade de "apreender, deter pessoas e levá-las para os campos de reeducação" (NÃO..., 2010), e que o SNASP dependia diretamente do chefe do partido, e não do governo, configurando-o como um instrumento essencial para perseguir os fins revolucionários, inclusive perseguir os supostos inimigos. Os dados reportados dizem que no campo de M'telela devem ter entrado cerca de 1.800 indivíduos, apenas 100 saindo com vida (BERNARDO, 2004). Dai a conclusão de que "o recurso à eliminação física parece ter sido uma componente 'normal' da luta política no seio da Frelimo" (SANTOS, 2004).

Da mesma forma, o Macuablogs enfatiza a aprovação de leis especiais, contrárias aos direitos humanos, tais como as de 1978 e de 1979, que introduzem a pena de morte e o Tribunal Militar Revolucionário. O blogue recorda que a própria Amnesty International interveio (assim como fez em 1983, na altura da Operação-Produção), denunciando a vaga de capturas por razões políticas e o envio dos detidos em campos de reeducação, nomeadamente Chaimite e Ruarua, pedindo a conversão das penas de morte em pena de prisão (TRIBUNAL..., 2006). As detenções foram tão difusas que Samora Machel, ao visitar o campo de Ruarua, ordenou a soltura de 684 detidos, todos ex-guerrilheiros da FRELIMO (TRIBUNAL..., 2006). Entre as testemunhas diretas, Fanuel Malhuza, antigo membro da FRELIMO que aderiu ao $\mathrm{COREMO}^{13}$, numa entrevista concedida a Salomão Moyana relata que em Ruarua, no campo de "Moçambique D", onde os "reacionários" eram detidos e eliminados, houve pessoas doentes enterradas vivas, além de torturadas e executadas (Moyana, 2000), como no caso do Silvério Nungo, tesoureiro da FRELIMO, acusado de ter participado na morte de Eduardo Mondlane. Nungo foi torturado a 18 de Julho de 1969 e, com parte do crânio aberto, teve uma agonia de 8 dias, no fim da qual encontrou uma morte "lenta e dolorosa" (CRAVEIRINHA, 2003).

\footnotetext{
${ }^{13}$ Comité Revolucionário de Moçambique, um pequeno partido com sede em Lusaca (Zâmbia) que, entre 1965 e 1974 lutou pela independência de Moçambique, principalmente na frente de Tete, parte centro-ocidental do país
} 
Entre as testemunhas valorizada pelo blogue há uma irmã católica italiana, Dalmazia Colombo, que em 2011 ficou arrepiada pela visita do local onde foram mortos, entre os outros, Estêvão Mirassi e o chefe islâmico de Lichinga, Ché Mussá, com uma vala comum ao lado de uma pista de aterragem para pequenos aviões e os restos de uma prisão (TESTEMUNHOS..., 2011).

O único artigo longo que Fernando Gil escreve em matéria de história tem a ver com a violação dos direitos humanos por parte da Frelimo. O motivo que desperta a atenção do Gil é a figura do Pedro Câmara que desertou com mais dois colegas seus - das Forças Armadas Portuguesas para se juntar à FRELIMO, de que foi depois eliminado. De acordo com as novas provas documentais, conseguidas no Arquivo histórico da Torre do Tombo em Lisboa, Gil conclui que Câmara e os seus dois colegas foram estrangulados por serem considerados agentes infiltrados da PIDE dentro da FRELIMO. Diferentemente daquilo que o General Pachinuapa, no seu livro, conta (PACHINUAPA, 2005), não existe nenhuma prova que confirme que Câmara e os outros dois pertenciam à PIDE mas, mesmo assim, foram brutalmente assassinados (CALIATE, 2015).

Uma última nota sobre os "campos de reeducação" deve ser feita a propósito do tratamento reservado às mulheres e a algumas minorias religiosas. No primeiro caso, no campo de Mswaíze (Niassa), "o sistema de 'reeducação' desumanizava a mulher, transformando-a em besta de carga, submetida à violência do trabalho forçado de sol a sol e privada de cuidados médicos e alimentação condigna" (NÃO..., 2010). No caso das Testemunhas de Jeová, estes costumavam ser concentrados no campo do Neisseko, também na província do Niassa, onde eram amarrados "com cordas embebidas em sal, o que inutilizou os membros superiores de muitas das vítimas" (NÃO..., 2010).

Em suma, a imagem que o macuablogs pretende promover da FRELIMO, sobretudo ao longo da luta de libertação e no período socialista é a de um partido feroz para com seus adversários políticos e desumano, em que o arbítrio reinava incontrastado, estendendo tais medidas até a cidadãos que nada tinham a ver com questões políticas. 


\section{Conclusões}

A pesquisa aqui apresentada quis compreender o papel exercido pela contranarrativa histórica representada pelo mauablogs. Embora sem querer estabelecer novas verdades históricas, a análise feita permitiu evidenciar as limitações da historiografia oficial moçambicana em alguns dos seus momentos centrais.

O macuablogs abriu um novo debate graças ao uso de fontes, orais e escritas, anteriormente silenciadas, havendo sempre presente uma explícita tendência anti-governamental. O blogue não visa expressar um ponto de vista imparcial, pois o que mais interessa é abrir o debate público sobre a história de Moçambique, metendo em dúvida as certezas da historiografia oficial.

Deste ponto de vista, o blogue gerido por Fernando Gil teve o grande mérito de abanar e alargar o debate no seio do país, mas a questão que se põe ao historiador profissional é se, depois de uma cuidadosa análise, os matérias trazidos poderão ser utilizados para reescrever partes do recente passado moçambicano.

A tentativa não passou despercebida. Em jeito de reação, a historiografia oficial, principalmente por intermédio de personagens da "velha Frelimo", tais como Sérgio Vieira e Paul Fauvet, além de intervenções por vezes reportadas no macuablogs em jornais governamentais (o Notícias e o Domingo em particular), procurou responder às novas hipóteses (e acusações) de forma geralmente "reativa", olhando pouco para os conteúdos propostos e usando a descredibilização das fontes como metodologia de debate. Em alternativa, foi escolhido o silêncio e o isolamento das novas vozes.

Um dos problemas centrais de Moçambique em relação à releitura do seu próprio passado é justamente este: por um lado, existem historiadores de fama internacional que continuam a desenvolver trabalhos interessantes, mas de impacto muito modesto dentro do país, pois seus textos são escritos geralmente em língua inglesa e em revistas que dificilmente chegam nas mãos dos moçambicanos; por outro, a contranarrativa histórica, iniciada com o citado livro de Ncomo, continua produzindo obras cujo posicionamento político é explícito, mas a consistência historiográfica nem sempre é confiável. No meio, a academia 
moçambicana gagueja, numa condição de aperto entre universidades públicas em que a releitura do passado é praticamente banida, e as privadas em que a atividade de pesquisa é extremamente reduzida. Única exceção é representada por centros de pesquisa privados, tais como o IESE (Instituto de Estudos Económicos e Sociais) cujo foco, porém, não está em olhar para o passado, mas para o presente e, por vezes, o futuro.

Diante desta situação o papel de blogues tais como o macuablogs resulta decisivo, se não por reescrever de forma sistemática o passado nacional, pelo menos para despertar a atenção em relação a uma possibilidade de uso de novas fontes, saindo assim da cristalização historiográfica que o país está atravessando pelo menos desde o início da Segunda República.

\section{Referências}

ACABOU-SE o medo. O Autarca. Beira, 30 ago. 2004. Disponível em: https://macua.blogs.com/moambique_para_todos/2004/08/acabouse_o_medo. html. Acesso em: 10 nov. 2018.

AKE, Claude. Democracy and development in Africa. Dakar: Codesria, 1995.

ALAR, Julião. A história de Moçambique não existe. Brasil Escola. Goiana, 1991. Disponível em: https://meuartigo.brasilescola.uol.com.br/historia/a-historiamocambique-nao-existe.htm. Acesso em: 16 abr. 2019.

ALEGADA estátua de André Matsangaíssa será removida na Rotunda da Munhava. O Autarca. Beira, 29 maio 2009. Disponível em: https://macua.blogs.com/moambique_para_todos/2009/05/alegada-estátuade-andré-matsangaissa-será-removida-na-rotunda-da-munhava.html. Acesso em: 10 nov. 2018.

ARAÚJO, Cristóvão. Dia 25 de setembro: comemora-se o 54ㅇa aniversário de início da Luta Armada de Libertação Nacional. Sapo. [Lisboa], 25 set. 2018. Disponivel em: https://macua.blogs.com/moambique_para_todos/2018/09/dia25-de-setembro-comemora-se-o-54-aniversário-do-início-da-luta-armadade-libertação-nacional.html. Acesso em: 04 jul. 2019.

ARAÚJO, Manuel de. Será "Simango, uma obra, uma causa" a Bíblia alternativa? Zambézia online. Quelimane, 22 ago. 2004. Disponível em: https://macua.blogs.com/moambique_para_todos/2004/08/ser_simango_uma.h tml. Acesso em: 30 jun. 2018. 
ASSASSÍNIO de Eduardo Mondlane. Macuablogs. Lisboa, 11 jun. 2004. Disponível em:

https://macua.blogs.com/moambique_para_todos/2004/06/assassnio_de_ed.ht ml., Acesso em: 12 jul. 2019.

BARBOSA RIBEIRO, Fábia. Educação e ensino de história em contextos coloniais e pós-coloniais. Mneme - Revista de Humanidades, Natal, v. 16, n. 36, p. 27-53, 2015. Disponível em:

https://webcache.googleusercontent.com/search?q=cache:I3gvqrhOsfUJ:https:// periodicos.ufrn.br/mneme/article/download/8069/6123/0+\&cd=2\&hl=ptBR\&ct=clnk\&gl=br. Acesso em: 30 jun. 2018.

BARROSO, Marta. Eu não tenho a minha versão da morte de Mondlane, mas a versão, diz Sérgio Vieira. DW. Lisboa, 25 jun. 2014. Disponível em: https://m.dw.com/pt-002/eu-não-tenho-a-minha-versão-da-morte-demondlane-mas-a-versão-diz-sérgio-vieira. Acesso em: 12 jul. 2019.

BERNARDO, Manuel Amaro. Crimes da Frelimo antes e depois da independência. Diário de Notícias. Lisboa, 04 out. 2004. Disponível em: https://macua.blogs.com/moambique_para_todos/2012/12/crimes-da-frelimoantes-e-depois-da-independênciarepetição.html. Acesso: 12 jul. 2019.

BESSA RIBEIRO, Fernando. A invenção dos heróis: nação, história e discursos de identidade em Moçambique. Etnográfica, Lisboa, v. IX, n. 2, p. 257-275, 2005.

BORGES COELHO, João Paulo. Política e história contemporânea em Moçambique. Revista de História, São Paulo, n. 178, p. 1-19, 2019. Disponível em: https://www.revistas.usp.br/revhistoria/article/view/146896/155735. Acesso: 03 fev. 2020.

BUSSOTTI, Luca. A gestão do "risco político" na democracia moçambicana. Estudos de Sociologia, Recife, v. 2, n. 20, 2014. Disponível em:

https://periodicos.ufpe.br/revistas/revsocio/article/view/235557/28524. Acesso: 03 fev. 2020.

CABAÇO, José Luís. Moçambique: Identidade, colonialismo e libertação. São Paulo: Anpocs, 2009.

CABRITA, João. A morte de Samora Machel. Maputo: Edições Novafrica, 2005a.

CABRITA, João. Malawi alvo de guerra de Samora Machel. Mediafax. Maputo, 31 out. 2005. Disponível em:

https://macua.blogs.com/moambique_para_todos/2005/10/malawi_alvo_de_.ht ml. Acesso em: 22 jul. 2019.

CABRITA, João. Autor de "A morte de Samora Machel" responde a Sérgio Vieira. Domingo. Maputo, 18 dez. 2005. Disponível em:

https://macua.blogs.com/moambique_para_todos/2005/12/srgio_vieira_co.html. Acesso em: 22 jul. 2019. 
CAHEN, Michel. Estado sem nação. Bourdeaux: Université de Bourdeaux, 1992.

CAHEN, Michel. Les bandits: un historien au Mozambique. Paris: Centre Culturel Calouste Gulbenkian, 2002.

CAHEN, Michel. The Enemy as Model. In: OXPO Working Papers. Oxford: [s.n.], 2011. Disponível em: www.politics.ox.ac.uk. Acesso: 22 jul. 2019.

CALIATE, Zeca. História da Frelimo: o assassinato do zambeziano Pedro Câmara. In: MACUABLOGS. Lisboa, 29 jul. 2015. Disponível em:

https://macua.blogs.com/moambique_para_todos/2015/07/história-da-frelimoo-assassinato-do-zambeziano-pedro-câmara.html. Acesso em: 22 jul. 2019.

CARVALHO, Sol; SERRA, Carlos; MOREIRA, José. História de Moçambique. Maputo: Tempo, 1988. v. 1.

CHIPANDE reitera ter disparado o primeiro tiro. Macuablogs. Lisboa, 26 set. 2008. Disponível em: https://macua.blogs.com/moambique_para_todos/2008/09/chipandereiter.html. Acesso em: 03 fev. 2020.

COLE, Juan. Blogging current affairs history. Journal of Contemporary History, Thousand Oaks, v. 46, n. 3, p. 658-670, 2011.

CRAVEIRINHA, João. Na frente de libertação: a clarificação total. Tribuna. Maputo, 5 dez. 2003a. Disponível em:

https://macua.blogs.com/moambique_para_todos/2004/06/na_frente_de_li.htm l. Acesso em: 03 fev. 2020.

CRAVEIRINHA, João. Metelela: Uria Simango e os outros. Demos. Maputo, 2003b. Disponível em:

https://macua.blogs.com/moambique_para_todos/2004/08/metelela_uria_s.ht ml. Acesso em: 03 fev. 2020.

CRAVEIRINHA, João. A propósito de Chai ou onda de ressentimento colonial? Macuablogs. Lisboa, 2004. Disponível em https://macua.blogs.com/moambique_para_todos/2004/09/especial_25_de_ht ml. Lisboa, 25 set. 2004. Acesso em: 03 fev. 2020.

DAVIDSON, Basil. Old Africa rediscovered. London: Victor Gollancz Ltd, 1959.

DAVIDSON, Basil. Which way Africa? London: Penguin, 1971.

DINERMAN, Alice. Moçambique depois do socialismo. Relações Internacionais, Lisboa, n. 15, p. 101-124, 2007. Disponível em:

http://www.ipri.pt/images/publicacoes/revista_ri/pdf/ri15/RI15_10ADinerman.pdf. Acesso em: 03 fev. 2020.

ELLIS, Stephen. Writing history in contemporary Africa. The Journal of African History, Cambridge, v. 43, n. 1, p. 1-26, 2002. 
FALOLA, Toyin. Writing and teaching national history in Africa in an era of global history. Africa Spectrum, Hamburg, v. 40, n. 3, p. 499-519, 2005.

FAUVET, Paul. Não escrever a história a partir dos restos do apartheid. Savana. Maputo, 4 nov. 2005. Disponível em:

https://macua.blogs.com/moambique_para_todos/2010/11/não-escrever-ahistória-a-partir-dos-restos-do-apartheid-repetição.html. Acesso: 15 abr 2019

FRELIMO sabia do risco que Mondlane corria em Dar-es-Salaam. O País. Maputo, 27 fev. 2012. Disponível em:

https://macua.blogs.com/moambique_para_todos/2012/02/frelimo-sabia-dorisco-que-mondlane-corria-em-dar-es-salaam.html. Acesso em: 04 jul. 2019.

FUNADA CLASSEN, Sayaka. The origins of war in Mozambique. South Africa: African Minds, 2013.

GIL, Fernando. Sobre a fundação da Frelimo em Accra (Gana). Macuablogs. Lisboa, 21 nov. 2011. Disponível em:

https://macua.blogs.com/moambique_para_todos/2011/11/page/2/. Acesso em: 15 abr. 2019

GIL, Fernando. Nota sobre o artigo A história de Moçambique devia ser reconstruída, defendem académicos e políticos. DW. Lisboa, 25 jun. 2018. Disponível em: https://www.dw.com/pt-002/a-história-de-moçambique-deviaser-reconstituída-defendem-académicos-e-políticos/a-44392300. Acesso em: 15 abr. 2019.

GIL, Fernando. Entrevista sobre história de Moçambique. Mensagem recebida por email, 25 nov. 2019.

HANLON, Joseph. Mozambique: "The war ended 17 years ago, but we are still poor". Conflict, Security \& Development, London, v. 10, n. 1, p. 77-102, 2020. Disponível em: htts://www.tandfonline.com. Acesso em: 16 mar. 2021.

\section{HANLON, Joseph; SMART, Teresa. Do bicycles equal development in}

Mozambique? Woodbridge: James Currey, 2008.

HEDGES, David et al. História de Moçambique. Maputo: Imprensa Universitária, 1993. v. 3.

$\mathrm{HO}$, Stephane. Blogging as popular history making, blogs as public history: a Singapore case study. Public Historic Review, Broadway, v. 14, p. 64-79, 2007. Disponível em: https://espress.lib.uts.edu.au. Acesso em: 15 abr. 2019.

HOBSBAWM, Eric. Introduction: inventing traditions. In: HOBSBAWM, Eric; RANGER, Terence. The invention of tradition. Cambridge: Cambridge University Press, 1983. p. 1-14.

ISAACMAN, Allen. Newitt, Malyn. A short history of Mozambique. The American Historical Review, Oxford, v. 124, Issue 1, p. 392-394, 2019. Disponível em: https://academic.oup.com. Acesso em: 16 mar. 2021. 
JESUS, José Manuel Duarte de. Eduardo Mondlane: Um homem a abater. São Paulo: Edições 70, 2010.

JUNQUEIRA BARRETO, Isabel de Sousa Lima. Construção de heróis nacionais em Portugal e Moçambique: os casos de Mouzinho de Albuquerque e Ngungunhana. In: SIMPÓSIO NACIONAL DE HISTÓRIA, 26., São Paulo, jul. 2011. Anais [...]. São Paulo: ANPUH, 2011. Disponível em: http://www.snh2011.anpuh.org/resources/anais/14/1300569133_ARQUIVO_Comu nicacaoANPUH2011lsabelBarreto.pdf. Acesso em: 16 maio 2019.

LAS. Livro critica falhas da segurança na morte de Samora Machel. Lusa-RTP. Lisboa, 19 out. 2005. Disponível em: https://www.rtp.pt/noticias/mundo/livrocritica-falhas-da-seguranca-na-morte-de-samora-machel_n116849. Acesso em: 16 maio 2019.

MACAGNO, Lorenzo. Fragmentos de uma imaginação nacional. Revista Brasileira de Ciências Sociais, São Paulo, v. 24, n. 70, p. 17-35, 2009. Disponível em: http://www.scielo.br/pdf/rbcsoc/v24n70/a02v2470.pdf. Acesso em: 16 mar. 2021.

MANU disparou o primeiro tiro e não a Frelimo. Imparcial. Maputo, 20 set. 2002. Disponivel em:

https://macua.blogs.com/moambique_para_todos/2015/09/manu-disparouprimeiro-tiro-e-não-a-frelimo-em-agosto-de-1964.html. Acesso: 12 set 2019.

MENESES, Maria Paula. Xiconhoca, o inimigo. Revista Crítica de Ciências Sociais. Coimbra, 106, p. 9-52, 2015. Disponível em:

https://journals.openedition.org/rccs/5869. Acesso em: 16 mar. 2021.

MENESES, Maria Paula; SANTOS, Boaventura de Sousa. Mozambique: the rise of a Micro Dual State. Africa Development. Dakar, v. XXXIV, n. 3/4, p. 129-166, 2009.

MENSAGEM alusiva ao 36 aniversário da morte do Primeiro Comandante em Chefe das Forças de Resistência Nacional Moçambicana, André Matala Matsangaísse. Comunicado do partido Renamo [Maputo], 17 out. 2015. Disponivel em: https://macua.blogs.com/moambique_para_todos/2015/10/mensagem-alusivaao-36-aniversário-da-morte-do-primeiro-comandante-em-chefe-das-forçasda-resistência-nacional-moçambic.html. Acesso em: 16 mar. 2021.

MOYANA, Salomão. Fanuel Malhuza continua a desafiar as teses da Frelimo sobre a História. Savana. Maputo, 27 out. 2000. Disponível em:

https://macua.blogs.com/moambique_para_todos/2011/01/fanuel-malhuzacontinua-a-desafiar-as-teses-da-frelimo-sobre-a-história.html. Acesso em: 16 mar. 2021.

MOYANA, Salomão. É tempo de dizer a verdade sobre Mbuzini! Zambeze. Maputo, 20 out. 2005. Disponivel em: https://macua.blogs.com/moambique_para_todos/morte_samora_machel_/inde x.html. Acesso em: 16 mar. 2021. 
MUIANGA, Benedito. Sobre o assassinato de Filipe Samuel Magaia. Savana, Maputo, 06 out. 1995. Disponível em:

https://macua.blogs.com/moambique_para_todos/2007/05/sobre_o_assassi.ht ml. Acesso em: 16 mar. 2021.

NEWITT, Malyn. A History of Mozambique. Bloomington: Indiana University Press, 1995.

NÃO ao regresso dos campos de reeducação. Canalmoz, Maputo, 15 out. 2010. Disponível em: https://macua.blogs.com/moambique_para_todos/2010/10/nãoao-regresso-dos-campos-de-reeducação.html. Acesso em: 16 maio 2019.

NHACHOTE, Luís. Adelino Chitofo Gwambe: um desafio para os historiadores. Canal de Moçambique, Maputo, 2005. Disponível em: https://macua.blogs.com/moambique_para_todos/2006/02/adelino_chitofo.htm l. Acesso em: 16 maio 2019.

NHACHOTE, Luís. O insólito caso da moçambicana fuzilada. Canal de Moçambique. Maputo, 2000a. Disponível em:

https://macua.blogs.com/moambique_para_todos/2006/06/tribunal_judici.html. Acesso: 25 jul. 2019

NHACHOTE, Luís. Caso Joana Simeão. Canal de Moçambique. Maputo, 29 jun. $2000 \mathrm{~b}$.

NHACHOTE, Luís. Eduardo Mondlane morreu em casa da Betty King. Canal de Moçambique, Maputo, 07 fev. 2006. Disponível em:

https://macua.blogs.com/moambique_para_todos/2006/02/eduardo_mondlan.h tml. Acesso em: 16 maio 2019.

NHACHOTE, Luís. Mtelela: os crimes da Frelimo. Canal de Moçambique. Maputo, 23 jul. 2009. Disponível em:

https://macua.blogs.com/moambique_para_todos/mtelela_niassa/. Acesso em: 16 maio 2019.

NGOENHA, Severino. Machel: ícone da Primeira República? Maputo: Ndjira, 2010.

OGOT, Bethwell. African historiography: from colonial historiography to UNESO's general history of Africa. [S.l.: s.n.], 2011. Disponível em: rjh.ubb.rug.nl. Acesso em: 16 maio 2019.

O MAPA do primeiro combate (25.09.1964) na versão de Chipande e nos reparos da SCCIM (Repetição). Macuablogs. Lisboa, 25 set. 2019. Disponível em: https://macua.blogs.com/moambique_para_todos/2017/03/o-mapa-doprimeiro-combate-25091964-na-versão-de-chipande-e-os-reparos-dossccim.html. Acesso em: 08 out. 2020.

PACHINUAPA, Raimundo Domingos. Do Rovuma ao Maputo. Maputo: [s.n.], 2005.

PATRAQUIM, Luís Carlos. Processo democrático em Curso. O Mundo em Português, Lisboa, n. 3, 1999. Disponível em: 
https://macua.blogs.com/moambique_para_todos/2005/02/processo_democr.h tml. Acesso em: 08 out. 2020.

PIIRIMÄE, P. Official historiography and the state in early modern Europe. Storia della Storiografia, Torino, v. 71, n. 1, p. 47-76, 2017.

RATTI, Piero. La storia dei vincitori e i suoi miti. Viareggio: Dissensi, 2013.

RELATO de uma guerra sem primeiro tiro. O País. Maputo, 25 set. 2010. Disponível em:

https://macua.blogs.com/moambique_para_todos/2010/09/relato-de-umaguerra-sem-primeiro-tiro.html. Acesso em: 03 mar. 2018.

SABEM quem foi o tipo que içou a bandeira de Moçambique, no estádio da Machava, no dia 25 de Junho de 1975 (Dia da Independência)? Macuablogs. Lisboa, 25 out. 2007. Disponível em: https://macua.blogs.com/moambique_para_todos/2007/10/sabem-quem-foi.html\#: :text=Também\%20fiquei\%20admirado\%20quando\%20hoje,de\%201975\% 20chamava-se\%20André. Acesso em: 01 ago. 2019.

SALVADOR, José. Introdução à coletânea de textos intitulada Samora Machel. In: A LUTA CONTINUA. Queluz: [s.n.], 1974. Disponível em: https://wwww.novacultura.info/single-post/2018/09/24/A-FRELIMO-e-o-povomoçambicano-em-armas. Acesso em: 01 ago. 2019.

SANTOS, Boaventura de Sousa. Moçambique por contar. Visão. Lisboa, 26 ago. 2004. Disponível em: https://macua.blogs.com/moambique_para_todos/2004/08/moambique_por_c. html. Acesso em: 09 abr. 2019.

SÉRGIO Vieira manipula factos sobre morte de Mondlane. Zambeze. Maputo, 26 fev. 2009. Disponível em:

https://macua.blogs.com/moambique_para_todos/2009/02/sérgio-vieiramanipula-factos-sobre-morte-de-mondlane-1.html. Acesso em: 10 abr. 2019.

SERRA, Carlos (org.). História de Moçambique. Maputo: Imprensa Universitária, 1983. v. 2.

SIMBINE, Domingos. Quem matou Samora Machel? Diário da Zambézia. Quelimane, 27 nov. 2006. Disponível em:

https://macua.blogs.com/moambique_para_todos/2006/02/20_anos_depois_ht ml. Acesso em: 09 abr. 2019.

SOUSA JR, Fernando de. O nacionalismo africano no caminho para a democracia: a transição do poder colonial para o partido único nos PALOP. Lisboa: CESA/ISEG, 2013. Disponível em: https://cesa.rc.iseg.ulisboa.pt/RePEc/cav/cavwpp/wp119.pdf. Acesso em: 10 abr. 2019. 
TESTEMUNHOS da religiosa italiana sobre o local do holocausto moçambicano. Canal de Moçambique. Maputo, 28 nov. 2011.

THOMAZ, Oscar Ribeiro. "Escravos sem donos": a experiência social dos campos de trabalho em Moçambique no período socialista. Revista de Antropologia, São Paulo, v. 51, n. 1, p. 177-214, 2008.

TRIBUNAL Militar Revolucionário e a pena de morte em Moçambique. Canal de Moçambique. Maputo, 21 jul. 2006. Disponível em:

https://macua.blogs.com/moambique_para_todos/2014/01/tribunal-militarrevolucionário-e-a-pena-de-morte-em-moçambique.html. Acesso em: 09 abr. 2019.

URIA Simango e companhia imortalizados na Beira. Zambeze. Maputo, 15 jul. 2015. Disponível em:

https://macua.blogs.com/moambique_para_todos/2005/07/uria_simango_e_ht ml. Acesso em: 13 nov. 2018.

VIEIRA, Sérgio. A rota externa para a formação e consolidação da Frelimo.

Boletim Informativo do Partido Frelimo. Maputo, n. 4.171, 2005a. Disponível em: https://macua.blogs.com/moambique_para_todos/2006/01/a_rota_externa_2.h tml. Acesso em: 16 abr. 2019.

VIEIRA, Sérgio. Carta a muitos amigos. Domingo, Maputo, p. 11, 04 dez. 2005b.

VINES, Alex. Renamo's rise and decline: the politics of reintegration in Mozambique. International Peacekeeping, London, n. 20, v. 3, p. 375-393, 2013. 